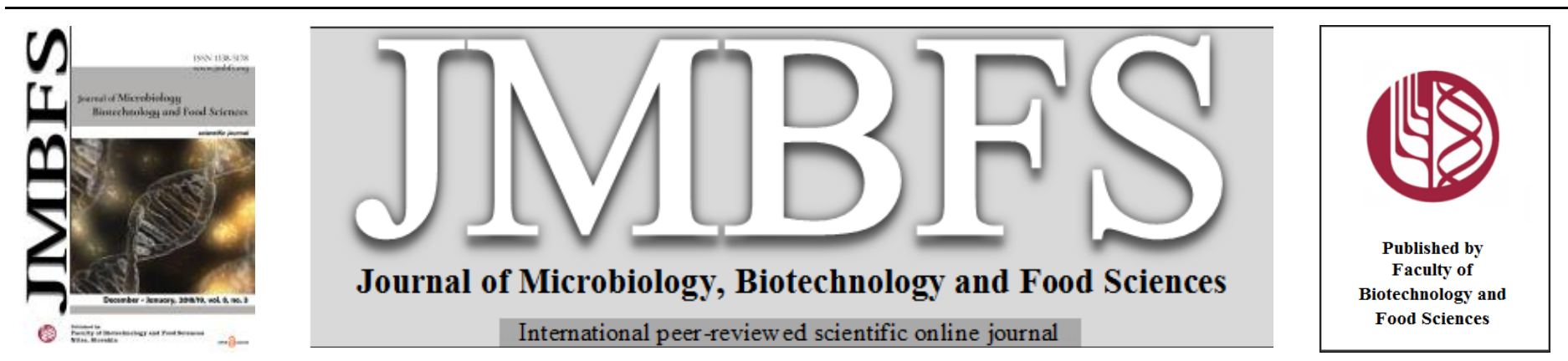

\title{
CHEMICAL CHARACTERIZATION AND ANTIMICROBIAL ACTIVITY OF SOME ESSENTIAL OILS AFTER THEIR INDUSTRIAL LARGE-SCALE DISTILLATION
}

\author{
Ivan Salamon ${ }^{1}$, Maryna Kryvtsova ${ }^{2}$, Daniel Bucko ${ }^{3}$, Amer H. Tarawneh ${ }^{4}$ \\ Address(es): \\ ${ }^{1}$ University of Presov, Faculty of Humanities and Natural Science, Department of Ecology, 01, 17th November St., 081 16, Presov, Slovakia. \\ ${ }^{2}$ Uzhhorod National University, Biological Faculty, Department of Genetics, Plant Physiology and Microbiology, 32, Voloshyn St..,88000, Uzhhorod, Ukraine. \\ ${ }^{3}$ Calendula, Co., Nova Lubovna 238 A, 06511, Slovakia. \\ ${ }^{4}$ Tafila Technical University, Department Of Chemistry and Chemical Technology. P.O.Box 179 Tafila 66110 Jordan.
}

*Corresponding author: maryna.krivcova@gmail.com

doi: 10.15414/jmbfs.2018.8.3.965-969

ARTICLE INFO

Received 15. 8. 2018

Revised 26. 10. 2018

Accepted 19. 11. 2018

Published 1. 1. 2019

Regular article

OPEN $\partial_{\text {ACCESS }}$

\begin{abstract}
Essential oils (EOs) are complex mixtures of several components that show a wide range of biological activities. The objective of the present work was to investigate the composition of the essential oils from industrial large-scale distillation, and evaluate their antimicrobial activity on typical and clinic isolates strains. The qualitative compositions of essential oils of several aromatic plants were determined by GC-FID after their industrial large-scale distillation (Calendula Co., Nova Lubovna, Slovakia). GC-FID analysis revealed that essential oils from large-scale show different qualitative and quantitative content in comparison with literature data. Eleven essential oils, namely, Rosmarinus officinalis L., Thymus vulgaris L., Menta ×piperita L., Matricaria recutita L., Hyssopus officinalis L., Salvia officinalis L., Pimpinella anisum L., Juniperus communis L., Abies alba L., Pinus silvestris L., and Coriandrum sativum L. were tested for their antimicrobial activities using disk diffusion method. Thymus vulgaris $\mathrm{L}$. essential oil shows the most potent antimicrobial activity. On other hand, the essential oil of Hyssopus officinalis L., Mentha $\times$ piperita L., Rosmarinus officinalis L., and Coriandrum sativum $\mathrm{L}$.. The essential oil show medium antimicrobial activity. There was no antimicrobial activity observed for Matricaria recutita L.
\end{abstract}

Keywords: essential oil content, chemical analysis, constituents, large-scale distillation, antimicrobial activity

\section{INTRODUCTION}

Over the past few decades, research has focused on the health effects of phytochemicals and plant-derived extracts (Newman and Cragg, 2007). In recent years, the varied therapeutic potential of EOs attracted the attention of researchers for their antimicrobial activity (Hercules et. al., 2017; Inouye $\boldsymbol{e t}$. al., 2001; Rota et al., 2004). Modern pharmaceutical science is showing high degree of towards the herbal products as compared to the synthetic products. Herbal medicine is considered to have better affordability, acceptability and compatibility with the human physiology and minimal side effects (Al-Asmari et. al., 2014). The use of herbal products for the medicines, perfumery, cosmetics and food industry and agriculture are increasing among common people, patients and physicians as evident form an increased market of herbal medicine (Bernal et al., 2013; Musthaba et. al., 2010).

In recent years, large improvement in breeding methods, cultivation, harvesting and processing techniques make produce EOs in large scale possible. Calendula, Co. Company in Nova Lubovna, Slovakia is considered as one of the leader regards to large production of EOs. This company has been producing medicinal EOs and extracts since 1999 (Salamon, 2014). The composition of the aromatic and volatile oils are influenced by ecological, genotype and technological such as; cultivation, types of collection, storage of crude material and processing technique (Mancini et. al., 2015). Interestingly, EOs yield and composition from miniature research distillation equipment are differed from large commercial distilleries for aromatic plant of the same species (Mitchell and Crowe, 1996).

As the effect of large scale production on the quantitative and qualitative content are known, this study attempt was made to characterize the chemical composition of the eleven aromatic plants raw-material after industrial large-scale distillation and investigate the effect of large scale production on their antimicrobial activities.

\section{MATERIAL AND METHODS}

The raw materials of different aromatic plant species: Juniper (Juniperus communis L.), Coriander (Coriandrum sativum L.), Pine ( Pinus silvestris L.), Fir (Abies alba L.), Anise (Pimpinella anisum L.), Sage (Salvia officinalis L.), Hyssop (Hyssopus officinalis L.), Chamomile (Matricaria recutita L.),
Peppermint ( Mentha xpiperita L.), Thyme (Thymus vulgaris L)., Rosemary (Rosmarinus officinalis L.) for large-scale essential oil isolation were donated by established growers in Slovakia (Agrokarpaty, Ltd., Plavnica, Biovex, Ltd., Michalovce and Mipros, Ltd., Nitra) and imported from cooperation companies in Poland (Herbar, Ltd., Milejow), Czech Republic (Prvni jilovska, Co., Jilove u Prahy) and Ukraine (Sumyfitofarmacia, Ltd., Sumy). The raw stock presents different fresh and dry plant parts (fruits, herbs, needles, flowers and seeds), which are chopped afore distillation process.

\section{Isolation of essential oils}

EOs were obtained by the large-scale distillation apparatus (Oravec $\boldsymbol{e t}$ al., 1988 ) specifically designed for aromatic and medicinal plants. There are two types of distillation apparatus; type ' HV-3000 ' (height: $5,250 \mathrm{~mm}$, width: $2,180 \mathrm{~mm}$, with container for $200-250 \mathrm{kgs}$ of dried plant material and for $400-500 \mathrm{kgs}$ of fresh plant material) and type ' HV-300 ' (height: $3,400 \mathrm{~mm}$, width: $1,300 \mathrm{~mm}$, with container for $40-50 \mathrm{kgs}$ of dry plant material and $100-120 \mathrm{kgs}$ of fresh plant material). Both types were developed and technologically upgraded from 2000 to 2007 (Bucko and Salamon, 2007), and proved to be very successful by Calendula Co., in Nova Lubovna, Slovakia (Fig. 1). The first type is used for larger quantities of plant raw materials during their harvest and transport from cultivation fields. The second type for lower quantities of dry plant parts during a winter time (outside a vegetation season). The mass yield of essential oil is higher in this case. The containers of EOs were stored under $\mathrm{N}_{2}$ at $+4{ }^{\circ} \mathrm{C}$ in a dark space. Each branches of EOs is determined on their chemical composition in regard to requirements of customers.

\section{GC-FID analyses}

The analysis of EOs was carried out using a gas chromatograph Varian 3090 , connected to MS Saturn 2100T integrator. The following operating conditions were used: capillary column: RX-5MS, $30 \mathrm{~m}$ x $0.250 \mathrm{~mm}$ i.d., film thickness: $0.25 \mu \mathrm{m}$, carrier gas: $\mathrm{He}_{2}$, adjusted to a flux of $1.5 \mathrm{ml} / \mathrm{min}$, injection and FIDdetector temperatures: $220^{\circ} \mathrm{C}$ respectively $250{ }^{\circ} \mathrm{C}$, a capacity of sample injection: $2 \mu \mathrm{l}$, MS-detector with automatic injector type 1177 . 
Components were identified by their GC retention times, and the resulting values were comparable to those of literature. Oil component standards for comparison were supplied by Extrasynthese, Merck, Fulka, Sigma a Roth.

\section{Antimicrobial activity}

Antimicrobial activity of EOs was determined using disk diffusion method Sterile filter paper disks ( $6 \mathrm{~mm}$ in diameter) impregnated with $10 \mu \mathrm{L}$ of essential oil was placed on the dish plate previously inoculated with a microbial suspension. Bacterium and yeast inocula $100 \mu \mathrm{L}$ in physiological solution were adjusted to the equivalent of $0.5 \mathrm{McFarland}$ standard, and evenly spread on Muller-Hinton agar surface (incubated at $37 \pm 2{ }^{\circ} \mathrm{C}$ for $24 \mathrm{~h}$ ), yeasts - on SDA agar (incubated at $35 \pm 2{ }^{\circ} \mathrm{C}$ for $48 \mathrm{~h}$ ). The diameters of the inhibition zones were measured in millimeters including diameter of disc (Rhos et al., 2005.). Each antimicrobial assay was performed at least three times.

As test culture, the following microorganisms from the ATTC (American Type Culture Collection, USA) collection were used: Candida albicans ATCC 885 653; Staphylococcus aureus ATCC 25923; Escherichia coli ATCC 25922, Enterococcus faecalis ATCC 29212, Streptococcus pyogenes ATCC 19615 Pseudomonas aeruginosa ATCC 27853. Also we used clinical strains of bacteria and yeast, which were isolated from sputum of different patients suffering from pneumonia, obstructive bronchitis, bronchial asthma, chronic obstructive disease and oral cavity patients with periodontal disease.

As a positive control were used: gentamicin $(10 \mathrm{mg} / \mathrm{disk})$ for Gram-negative bacteria, ampicilin (10 mg/disk) for Gram-positive bacteria, nystatin (100 UI) for Candida. As negative control were used DMSO.
For the results of experiment, we used statistical software Microsoft Office-Exce (2013) with the calculation of averages, error, and standard deviation.

\section{RESULTS AND DISCUSSION}

The large-scale technology of essential oil distillation in the Slovak Republic consists of a main distilling apparatus, a steam condenser, and an additional apparatus (Fig. 1). The shape of the main distilling apparatus is a funnel. It is thermal-isolated and made from stainless steel. An inside screw-plate is driven by an electric engine, which is installed on the apparatus. This screw-plate works as an exceptional stirrer. With regard to this system, the container has a mixing apparatus which is not a usual feature for many other types of commercia equipment. This is extremely useful for a complete distillation procedure and high yield of essential oils. The source of steam flow is a boiler (heated by oil, gas or electricity), and the flow is controlled mechanically, according to the plant mass and cooling needs. The length of distillation depends on medicinal plant species, which are used to isolate essential oils. Essential oil collector has a volume of 75 liter. (Bucko and Salamon, 2007)

In general, many factors could contribute to the differences between yield and composition of essential oils for industrial stills, for example, steam distribution, differences in size of the distillation unit, materials (such as glass versus aluminum), and temperature of condensing units (Mitchell and Crowe, 1996).

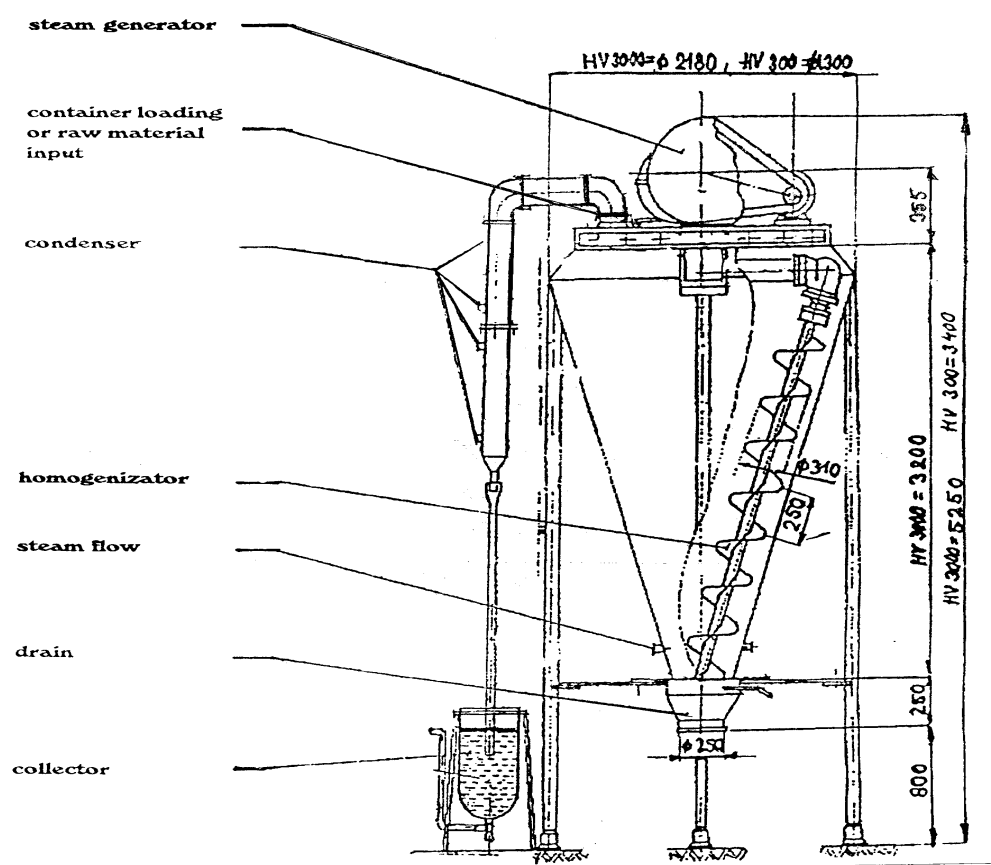

Figure 1 The large-scale distillation equipment using in the Slovak Republic by Calendula, Co. in Nova Lubovna, Slovakia

\section{Chemical composition of studied essential oils}

The EOs have received substantial attraction due to their significant biological usefulness (Miladi et al., 2013). The chemical composition of essential oil can also vary according to the geographical localization (Jaafari et al., 2007). In 1996, Mitchell and colleagues investigated whether a mini-still produces oil yield and composition similar to a larger commercial distillery. The result of their study revealed that was a different qualitative and quantitative content between mini-still produces and larger commercial production (Mitchell and Crowe, 1996). Table 1 shows the chemical composition of studied EOs. Highly active component $\alpha$-pinene found in high percent in composition of Juniperus communis L. and Pinus silvestris L. with 52 and $38 \%$, respectively. $\alpha$-pinene has been shown to have anti-inflammatory, antimicrobial and exhibits activity as an acetylcholinesterase inhibitor, aiding memory (Russo, 2011; Nissen et al., 2010). Whereas, (-)- $\alpha$-pinene is a positive modulator of GABAA receptors. It acts at the benzodiazepine binding site (Yang et al., 2016). Interestingly, Pimpinella anisum L. essential oil shows trans-, cis-anetholes as one major component with $89.3 \pm 1.5 \%$. This find is useful for herbal medicinal field Anetholes has wide range of biological activity (De M et. al., 2002; Bone and Mills, 2013).

Many searches revealed that the cytotoxic activity of Thymus vulgaris essentia oil towards cancer cells was mainly due to thymol. Table1 show that the two major contents for this plant specie are thymol and p-cymene with 32 and $40 \%$, respectively. The effect of large distillation can be recognized clearly compared with literature, for example the reported analysis for Thymus vulgaris major content thymol was found to be $49.1,41.33$ and $59.15 \%$ in three different studies (Nikolić et. al., 2014; Miladi et. al., 2013; Ramadan et. al., 2015). This variation in the quantitative content of EO is in agreement with previous study (Mitchell and Crowe, 1996).

Rosemary essential oil, for instance, contains mainly $\alpha$-pinene, p-cymene, $\alpha$ terpineol, camphor, camphene, cineole and $\beta$-pinene as major content. The larger commercial distilleries were nearly identical to mini-stills produced oil in regard to compare between the results, which we obtained and reported. (Santoyo et. al. 2005), but oil constituents differed between the two stills, which may have been resulted from dissimilar harvest and distillation practices (Mitchell and Crowe, 1996) 
Table 1 Chemical composition of studied essential oils of aromatic plants after a large-scale distillation and its qualitative-quantitative characteristics [\%, $\bar{x} \pm t \times s e]$

\begin{tabular}{|c|c|c|c|c|c|c|c|c|c|c|c|c|c|c|c|c|c|c|c|c|c|c|c|c|}
\hline Essential oils & $\alpha-P i$ & Bo & $\mathbf{c} / \mathbf{t A}$ & Men & p-Cy & LnL & BoA & $\alpha$-To & Bon & Cph & Met & Mrn & I-Me & Thy & Lim & Cam & BoS & Ch & ThJ & PiC & i-PiC & Cin & $\boldsymbol{\beta}-\mathbf{P i}$ & $\begin{array}{l}\text { Sa } \\
\mathbf{N}\end{array}$ \\
\hline $\begin{array}{l}\text { Rosmarinus } \\
\text { officinalis } \mathrm{L} \text {. }\end{array}$ & $\begin{array}{l}19.0 \\
\pm 1.0 \\
\end{array}$ & - & - & - & $\begin{array}{l}17.0 \\
\pm 1.0 \\
\end{array}$ & - & $\leq 2.0$ & $\begin{array}{c}2.5 \\
\pm 0.2 \\
\end{array}$ & $\begin{array}{c}2.0 \\
\pm 0.2 \\
\end{array}$ & $\begin{array}{l}19.0 \\
\pm 1.0 \\
\end{array}$ & - & - & - & - & - & $\begin{array}{c}9.0 \\
\pm 1.0 \\
\end{array}$ & - & - & - & - & - & $\begin{array}{l}25.0 \\
\pm 1.0 \\
\end{array}$ & $\begin{array}{c}5.0 \\
\pm 1.0 \\
\end{array}$ & - \\
\hline $\begin{array}{l}\text { Thymus } \\
\text { vulgaris } \mathrm{L} \text {. }\end{array}$ & - & - & - & - & $\begin{array}{l}40.0 \\
\pm 2.0 \\
\end{array}$ & - & - & - & - & - & - & - & - & $\begin{array}{l}32.0 \\
\pm 2.0 \\
\end{array}$ & - & - & - & - & - & - & - & - & - & - \\
\hline $\begin{array}{l}\text { Mentha } \\
\times \text { piperita } \mathrm{L} \text {. }\end{array}$ & - & - & - & $\begin{array}{l}39.0 \\
\pm 1.0 \\
\end{array}$ & - & - & - & - & - & $\begin{array}{c}15.0 \pm \\
0,6 \\
\end{array}$ & $\begin{array}{l}24.0 \\
\pm 1.0 \\
\end{array}$ & - & $\begin{array}{c}3.8 \\
\pm 0.2 \\
\end{array}$ & - & $\begin{array}{l}2.5 \\
\pm 0.2 \\
\end{array}$ & - & - & - & - & - & - & $\begin{array}{c}2.1 \\
\pm 0.1 \\
\end{array}$ & - & - \\
\hline $\begin{array}{l}\text { Matricaria } \\
\text { recutita L. }\end{array}$ & - & $\begin{array}{l}42.0 \\
\pm 1.0 \\
\end{array}$ & - & - & - & - & - & - & - & - & - & - & - & - & - & - & $\begin{array}{c}6.0 \\
\pm 0.2 \\
\end{array}$ & $\begin{array}{c}2.3 \\
\pm 0.2\end{array}$ & - & - & - & - & - & - \\
\hline $\begin{array}{l}\text { Hyssopus } \\
\text { officinalis L. }\end{array}$ & $\begin{array}{l}15.0 \\
\pm 1.0 \\
\end{array}$ & - & - & - & - & - & - & - & - & - & - & - & - & - & - & - & - & - & - & $\begin{array}{l}35.0 \\
\pm 2.0 \\
\end{array}$ & $\begin{array}{l}20.0 \\
\pm 1.0 \\
\end{array}$ & - & - & - \\
\hline $\begin{array}{l}\text { Salvia } \\
\text { officinalis L. }\end{array}$ & - & - & - & - & - & - & - & - & $\begin{array}{c}7.5 \\
\pm 0.5 \\
\end{array}$ & - & - & - & - & - & - & - & - & - & $\begin{array}{l}30.0 \\
\pm 1.0 \\
\end{array}$ & - & - & $\begin{array}{l}14.0 \\
\pm 1.0 \\
\end{array}$ & - & - \\
\hline $\begin{array}{l}\text { Pimpinella } \\
\text { anisum L. }\end{array}$ & - & - & $\begin{array}{l}89.3 \\
\pm 1.5 \\
\end{array}$ & - & - & $\begin{array}{c}1.3 \\
\pm 0.1 \\
\end{array}$ & - & $\leq 1.2$ & - & - & - & - & - & - & - & - & - & - & - & - & - & - & - & - \\
\hline $\begin{array}{l}\text { Juniperus } \\
\text { communis } \mathrm{L} \text {. }\end{array}$ & $\begin{array}{l}52.0 \\
\pm 2.0\end{array}$ & - & - & - & - & - & - & $\begin{array}{c}4.0 \\
\pm 0.5\end{array}$ & - & - & - & $\begin{array}{c}6.5 \pm \\
0.5\end{array}$ & - & - & $\begin{array}{l}18.0 \\
\pm 1.0\end{array}$ & - & - & - & - & - & - & - & $\begin{array}{c}2.0 \\
\pm 0.5\end{array}$ & $\begin{array}{c}4.5 \\
\pm 0 . \\
5\end{array}$ \\
\hline $\begin{array}{l}\text { Abies } \\
\text { alba } \mathrm{L} .\end{array}$ & $\begin{array}{l}15.0 \\
\pm 1.0 \\
\end{array}$ & - & - & - & - & - & $\begin{array}{l}18.0 \\
\pm 1.0 \\
\end{array}$ & - & $\begin{array}{c}2.2 \\
\pm 0.2 \\
\end{array}$ & - & - & - & - & - & $\begin{array}{l}24.0 \\
\pm 2.0 \\
\end{array}$ & - & - & - & - & - & - & - & - & - \\
\hline $\begin{array}{l}\text { Pinus } \\
\text { silvestris } \mathrm{L} .\end{array}$ & $\begin{array}{l}38.0 \\
\pm 2.0 \\
\end{array}$ & - & - & - & - & - & $\begin{array}{c}2.6 \\
\pm 0.2 \\
\end{array}$ & - & - & - & - & - & - & - & $\begin{array}{c}8.0 \\
\pm 1.0 \\
\end{array}$ & $\begin{array}{c}1.4 \\
\pm 0.2 \\
\end{array}$ & - & - & - & - & - & - & $\begin{array}{l}19.0 \\
\pm 1.0 \\
\end{array}$ & - \\
\hline $\begin{array}{l}\text { Coriandrum } \\
\text { sativum } \mathrm{L} \text {. }\end{array}$ & - & - & - & - & - & $\begin{array}{l}53.0 \\
\pm 2.0 \\
\end{array}$ & - & - & - & - & - & - & - & - & - & - & - & - & - & - & - & - & - & - \\
\hline
\end{tabular}

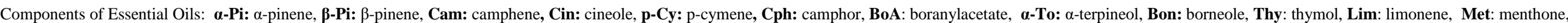

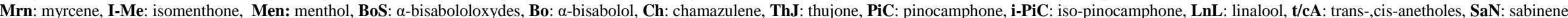




\section{Antimicrobial activity of essential oils}

Presently, there are a considerable number of studies on the antibacterial effect of EOs upon microorganisms; different plant chemotypes are also known to have different degrees of antimicrobial effect (Koščová et al., 2006; Kačániová et al. 2017). Up to our knowledge there is no study has been done on the antimicrobia activities of EOs prepared on industrial large scale. Both Table 2 and 3 shows the antimicrobial activities for eleven EOs namely, Rosmarinus officinalis L, Thymus vulgaris L, Mentha $\times$ piperita L, Matricaria recutita L., Hyssopus officinalis L. Salvia officinalis L., Pimpinella anisum L., Juniperus communis L., Abies alba L., Pinus silvestris L., and Coriandrum sativum L. tested on typical and clinical strain, respectively. A broad-spectrum antimicrobial activity of Thymus vulgaris EO founds against Gram-positive, Gram-negative bacteria and microscopic fungi of Candida genus (Table 2 and 3 ).

Table 2 Antimicrobial activities of the essential oils against typical strains

\begin{tabular}{|c|c|c|c|c|c|c|c|}
\hline № & Essential oils & $\begin{array}{c}\text { Staphylococcus } \\
\text { aureus } \\
\text { ATCC } 25923\end{array}$ & $\begin{array}{l}\text { Escherichia coli } \\
\text { ATCC } 25922\end{array}$ & $\begin{array}{c}\text { Enterococcus faecalis } \\
\text { ATCC } 29212\end{array}$ & $\begin{array}{c}\text { Streptococcus } \\
\text { pyogenes } \\
\text { ATCC } \\
19615\end{array}$ & $\begin{array}{l}\text { Pseudomonas } \\
\text { aeruginosa } \\
\text { ATCC } 27853\end{array}$ & $\begin{array}{c}\begin{array}{c}\text { Candida } \\
\text { albicans }\end{array} \\
\text { ATCC 885-653 }\end{array}$ \\
\hline 1 & Thymus vulgaris L. & $33.00 \pm 0.25$ & $12.66 \pm 0.33$ & $27.26 \pm 0.60$ & $12.70 \pm 0.44$ & - & $71.00 \pm 0.58$ \\
\hline 2 & Hyssopus officinalis L. & $17.00 \pm 0.20$ & $14.00 \pm 0.56$ & $8.33 \pm 0.33$ & $11.00 \pm 0.57$ & - & $11.50 \pm 0.20$ \\
\hline 3 & Mentha $\times$ piperita $\mathrm{L}$. & $12.00 \pm 0.10$ & $8.33 \pm 0.33$ & $9.66 \pm 0.17$ & $10.33 \pm 0.33$ & - & $15.00 \pm 0.57$ \\
\hline 4 & Rosmarinus officinalis L. & $8.33 \pm 0.33$ & $8.50 \pm 0.29$ & $7.83 \pm 0.44$ & $8.33 \pm 0.33$ & - & $12.33 \pm 0.33$ \\
\hline 5 & Coriandrum sativum $\mathrm{L}$. & $11.00 \pm 0.20$ & $15.50 \pm 0.29$ & $15.17 \pm 0.44$ & $11.00 \pm 0.25$ & - & - \\
\hline 6 & Abies alba $\mathrm{L}$. & - & $7.33 \pm 0.33$ & $10.00 \pm 0.15$ & - & - & $30.00 \pm 1.25$ \\
\hline 7 & Salvia officinalis L. & - & $9.83 \pm 0.44$ & $7.83 \pm 0.44$ & $8.33 \pm 0.33$ & - & $10.17 \pm 0.17$ \\
\hline 8 & Pimpinella anisum $\mathrm{L}$. & - & $9.83 \pm 0.44$ & $12.16 \pm 0.44$ & - & - & - \\
\hline 9 & Juniperus communis L. & $7.50 \pm 0.10$ & - & - & - & - & $15.00 \pm 0.25$ \\
\hline 10 & Pinus silvestris L. & - & - & $8.16 \pm 0.17$ & - & - & $8.00 \pm 0.10$ \\
\hline 11 & Matricaria recutita $\mathrm{L}$. & - & - & - & - & - & - \\
\hline
\end{tabular}

Zones inhibition, $\mathrm{mm}(\bar{x} \pm s)$; «-»- no inhibition.

Table 3 Antimicrobial activities of the essential oils against clinic strains,

\begin{tabular}{|c|c|c|c|c|c|c|}
\hline № & Essential oils & $\begin{array}{c}\text { Staphylococcus } \\
\text { aureus }\end{array}$ & $\begin{array}{c}\text { Escherichia } \\
\text { coli }\end{array}$ & $\begin{array}{c}\text { Streptococcus } \\
\text { pyogenes }\end{array}$ & $\begin{array}{c}\text { Pseudomonas } \\
\text { aeruginosa }\end{array}$ & $\begin{array}{l}\text { Candida } \\
\text { albicans }\end{array}$ \\
\hline 1 & Thymus vulgaris L. & $50.00 \pm 0.25$ & $25.33 \pm 0.88$ & $11.33 \pm 0.33$ & - & $38.00 \pm 0.80$ \\
\hline 2 & Hyssopus officinalis $\mathrm{L}$. & $20.00 \pm 0.10$ & $10.66 \pm 0.88$ & $11.33 \pm 0.33$ & - & $12.00 \pm 0.80$ \\
\hline 3 & Mentha $\times$ piperita $\mathrm{L}$. & $10.00 \pm 0.15$ & $9.00 \pm 0.58$ & $9.67 \pm 0.33$ & - & $10.00 \pm 0.25$ \\
\hline 4 & Rosmarinus officinalis L. & - & $8.00 \pm 0.10$ & $7.33 \pm 0.33$ & - & $13.00 \pm 0.50$ \\
\hline 5 & Coriandrum sativum $\mathrm{L}$. & $10.00 \pm 0.10$ & - & $11.00 \pm 0.58$ & - & $12.33 \pm 0.88$ \\
\hline 6 & Abies alba $\mathrm{L}$. & - & - & - & - & $20.00 \pm 1.15$ \\
\hline 7 & Salvia officinalis $\mathrm{L}$. & $12.00 \pm 0.10$ & $9.67 \pm 0.33$ & $8.00 \pm 0.57$ & - & $11.00 \pm 0.35$ \\
\hline 8 & Pimpinella anisum $\mathrm{L}$. & - & - & - & - & - \\
\hline 9 & Juniperus communis L. & $7.00 \pm 0.01$ & - & - & - & $21.33 \pm 0.88$ \\
\hline 10 & Pinus silvestris $\mathrm{L}$. & - & - & - & - & $10.00 \pm 0.58$ \\
\hline 11 & Matricaria recutita $\mathrm{L}$. & - & - & - & - & - \\
\hline
\end{tabular}

Zones inhibition, $\mathrm{mm}(\bar{x} \pm s)$; «-»- no inhibition.

Thyme EO shows strong antimicrobial effect on Staphylococcus aureus and Candida albicans. Regard to clinic strains, thyme oil shows potent effect on each of Staphylococcus aureus, Candida albicans and Escherichia coli with inhibition zone $50.00 \pm 0.25 \mathrm{~mm}, 38.00 \pm 0.80 \mathrm{~mm}$ and $25.33 \pm 0.88 \mathrm{~mm}$, respectively. Our results are in agreement with those obtained by Rota $\boldsymbol{e t}$ al (2004), they reported that Satureja montana and Thymus vulgaris EOs showed the high poten inhibitory effect against the gram-positive Listeria monocytogenes and Staphylococcus aureus, and the Gram-negative Salmonella enteritidis, Escherichia coli O157:H7, Yersinia enterocolitica, and Shigella flexneri. Furthermore, the result presented by Sakkas and Papadopoulou (2017) shows that Thyme oil has antibacterial activity on Escherichia coli, Campylobacter jejuni, Salmonella enteritidis, Pseudomonas aeruginosa, Klebsiella pneumonia In addition, these same oils exhibited moderate effects against multi-resistan clinical isolates namely; Acinetobacter baumannii, Escherichia coli, Klebsiella pneumoniae, and Pseudomonas aeruginosa, Table 2. Several previous studies reported that the essential oils of Thymus vulgaris, and their main phenolic constituents such as thymol show remarkable antimicrobial, antibacterial and antifungal activities (Raut et al., 2013; Laranjo et al., 2018; Rota et al 2004). Interestingly, thymol is one of the major content of Thymus vulgaris EO.

Essential oils of species Hyssopus officinalis L. and Mentha ×piperita L. show a broad spectrum of antimicrobial activity moderate potency. Whereas. Hyssopus officinalis EO inhibited the growth of Staphylococcus aureus, with growth inhibition zones $17.00 \pm 0.20 \mathrm{~mm}$ and $20.00 \pm 0.10$ for typical and clinical isolates, respectively. On the contrary, Hyssopus officinalis EO has more significan inhibition on typical strain $(14.00 \pm 0.56 \mathrm{~mm})$ than on clinical $(10.66 \pm 0.88 \mathrm{~mm})$ The antimycotic activity of the given essential oil against clinical and typical isolates was the same.

Rosmarinus officinalis L. essential oil had moderate level of antimicrobial activity, where antimycotic activities are $12.33 \pm 0.33$ and $13.00 \pm 0.50$ against typical and clinical isolates Candida albicans. Essential oil from Coriandrum sativum L. was active against Staphylococcus aureus, Escherichia coli, Enterococcus faecalis, Streptococcus pyogenes, with no antimycotic activity. This oil showed only effect on Escherichia coli.

Salvia officinalis L. essential oil showed low inhibition activity against Candida albicans and Eschericia coli. Also, has a low antimicrobial effect toward clinica staphylococcus with no activity against typical strains. Abies alba L. displayed remarkable selective antimycotic effect against Candida albicans in clinical strain.
EOs from Juniperus communis L., Pinus silvestris L., Matricaria recutita L. and Pimpinella anisum L. had weak antimicrobial and antimycotic activity.

In 2017, Reddy and collogues investigated the chemical composition and the antimicrobial activity for Mentha $\times$ piperita $\mathrm{EO}$ which cultivated in Saudi Arabia The major content is $36.02 \%$ of menthol and $24.56 \%$ of menthon which similar to the result reported in Table 1 . It is worth mentioning, the high similarity in the content of EOS was found but biological activity was significantly different (Reddy $\boldsymbol{e t}$. al., 2017). In the same manner, Semcniuc and colleagues (2017) show a higher activity of thyme EO against typical strains of Escherichia coli and Pseudomonas aeruginosa in comparison to thyme EO that reported in this study. Whereas, The Thymus vulgaris oil produced in large scale shows more expressed inhibiting effect toward Staphylococcus aureus.

Our results are concordant with Sharma et al. (2002) investigation regard to the anti-microbial activity of Coriandrum sativum L. EO, produced by mini steam distillation, toward Staphylococcus aureus and Candida albicans clinical strains. The work of Inouye et al. (2001) establishes the antibacterial activity of the essential oil samples obtained from various countries. It ascertains high antibacterial activity of Cinnamon oil and Thyme oil and moderate anti-microbia activity of Tea tree oil and Peppermint oil, which in fact fits with our data. Thereby, our study results shows that essential oils produced in large-scale distillation conditions had an antibacterial activity. According to literature data and our results there was some difference in antimicrobial activity.

\section{CONCLUSION}

Our results confirmed higher activity of EOs on Gram-positive bacteria and yeasts than against Gram-negative. They indicated that the highest activity was observed using EO from Thymus vulgaris L. The maximum antimycotic activity was shown by the EOs from Thymus vulgaris L. and Abies alba L.. Where each of Hyssopus officinalis L., Mentha $\times$ piperita L., and to Coriandrum sativum $\mathrm{L}$. EOs shows moderates antimicrobial activity. On other hand, the effect of EOs toward antibacterial clinical strains shows promising result and this open more area for further investigation. However their antimycotic activity against clinical strains of microscopic fungi was weaker than against their typical strains.

The obtained results have proved the need of further studies of the impact of essential oils upon bacterial isolates, including those with multiple resistances to medical preparations. The fact that phytomaterials much less often than antibiotics provoked the formation of resistance in bacteria and microscopic fungi 
may be considered as a motivation in favor of their use (Kryvtsova et.al, 2017).. Based on our knowledge this is the first study which investigate the antimicrobial activities of EOs from industrial large-scale distillation. Our data reveal that some EOs like Mentha $\times$ piperita L. and Thymus vulgaris $\mathrm{L}$. show variable antimicrobial activities than the one reported in the literature (Reddy et.al., 2017; Semcniuc at al., 2017 ), in spit their high similarity regard to the EOs content. In contrast, the results are concordant to other reported literature (Sharma et al. 2002; Inouye et al., 2001), the EO form Coriandrum sativum L. produced same activity toward Staphylococcus aureus and Candida albicans clinical strains. Further investigation is needed to develop and evaluate the factor that plays in this variation in biological activity.

Acknowledgments: The research was supported by the Slovak Research and Development Agency (SRDA) within the project No.: APVV-14-0843 "Research of possibilities of growing juniper (Juniperus communis L.) for the production of fruits".

Conflict of interest: The authors declare that they have no conflict of interest.

\section{REFERENCES}

AL-ASMARI AK, AL-ELAIWI AM, ATHAR MT, TARIQ M, AL EID A, AL ASMARY SM. 2014. A review of hepatoprotective plants used in Saudi traditional medicine. Evidence-Based Complementary and Alternative Medicine 1-22 http://dx.doi.org/ 10.1155/2014/890842

BERNAL, P., MOLINA S.C., DADDAOUA, A., LLAMAS, M.A. 2013 Antibiotic adjuvants: identification and clinical use. Microbial Biotechnology, 6:445-449. https://doi.org/10.1111/1751-7915.12044

BUCKO, D. SALAMON, I. 2007. The essential oil quality of chamomile, Matricaria recutita L., after its large-scale distillation. Acta Horticulturae, 749: 269-274. https://doi.org/10.17660/actahortic.2007.749.34

DE, M., DE A.K., SEN, P., BANERJEE, A.B. 2002. Antimicrobial properties of star anise (Illicium Verum Hook F). Phytotherapy Research. 16 (1): 94-5. https://doi.org/10.1002/ptr.989

INOUYE, S., TAKIZAWA, T., YAMAGUCHI, H. 2001. Antibacterial activity of essential oils and their major constituents against respiratory tract pathogens by gaseous contact. Journal of Antimicrobial Chemotherapy, 47(5):565-573 http://dx.doi.org/10.1093/jac/47.5.565

HERCULES, S., PAPADOPOULOU, C. 2017 Antimicrobial activity of basil, oregano, and Thyme essential oils. Journal of Microbiology and Biotechnology 27(3):429-438. https://doi.org/10.4014/jmb.1608.08024

KAČÁNIOVÁ, M., TERENTJEVA., M, VUKOVIC N, PUCHALSKI C, ROYCHOUDHURY S, KUNOVÁ S, KLŪGA A, TOKÁR M, KLUZ M IVANIŚOVÁ E. 2017. The antioxidant and antimicrobial activity of essential oils against Pseudomonas spp. isolated from fish. Saudi Pharmaceutical Journal, 25(8), 1108-1116. https://doi.org/10.1016/j.jsps.2017.07.005

BONE, K., MILLS, S.Y. 2013. Principles and practice of phytotherapy - modern herbal medicine. the $2^{\text {nd }}$ Edition. Churchill Livingstone Elsevier. Edinburgh, London, New York, Oxford, Philadelphia, St. Lois, Toronto, pp. 1051, ISBN 978-0-443-06992-5

KOŠČOVÁ J., NEMCOVÁ R., GANCARČÍKOVÁ S., JONECOVÁ Z., SCIRANKOVÁ L., BOMBA A., BULECA V. 2006. Effect of two plant extracts and Lactobacillus fermentum on colonization of gastrointestinal tract by Salmonella enterica var. Biologia, 61, 775-778. https://doi.org/10.2478/s11756 006-0156-Z

KRYVTSOVA, M., RIVIS, O., BABENKO, L., SPIVAK, N., NIKOLAICHUK, V., GANIC T. 2017. Antibacterial properties of essential oils against specific opportunistic pathogenic bacteria. Proceedings of $2^{\text {nd }}$ Japan - Turkey International Symposium on Pharmaceutical and Biomedical Sciences (JATUSPAB-2). p. 30.

LARANJO, M., FERNÁNDEZ-LÉON, A. M., POTES, M. E., AGULHEIROSANTOS, A. C., ELIAS, M. 2018. Use of essential oils in food preservation Antimicrobial research. Novel bioknowledge and educational programs (A Méndez-Vilas, Ed.) (in print).

MANCINI, E., SENATORE, F., DEL MONTE, D., DE MARTINO, L., GRULOVA, D., SCOGNAMIGLIO, M., SNOUSSI, M., DE FEO, V. 2015. Studies on chemical composition, antimicrobial and antioxidant activities of five Thymus vulgaris L. essential oils. Molecules; 20: 12016-28. https://doi.org/10.3390/molecules200712016

MITCHELL, A.R., CROWE, F.J.. 1996. Peppermint oil yield and composition from mini and industrial distilleries. Journal of Herbs, Species and Medicinal Plants. 4(1): 81-88. https://doi.org/10.1300/J044v04n01_10

MUSTHABA, M., BABOOTA, S., ATHAR, M.T., THAJUDEEN, K.Y., AHMED, S., ALI, J. 2010. Patented herbal formulations and their therapeutic applications. Recent Patents on Drug Delivery \& Formulation, 4(3): 231-244. https://doi.org/10.2174/187221110793237538

NIKOLIĆ, M., GLAMOČLIJA, J., FERREIRA, I.C., CALHELHA, R.C., FERNANDES, Â., MARKOVIĆ, T., MARKOVIĆ, D., GIWELI, A. AND SOKOVIĆ, M. 2014. Chemical composition, antimicrobial, antioxidant and antitumor activity of Thymus serpyllum L., Thymus algeriensis Boiss. and reut and Thymus vulgaris L. essential oils. Industrial Crops and Products, 52(2):183190. https://doi.org/10.1016/j.indcrop.2013.10.006

NEWMAN, D.J., CRAGG, G.M. 2007. Natural products as sources of new drugs over the last 25 years. Journal of Natural Products, 70(3): 461-477. https://pubs.acs.org/doi/full/10.1021/np068054v

NISSEN, L., ZATTA, A., STEFANINI, I., GRANDI, S., SGORBATI, B., BIAVATI, B., MONTI, A., 2010. Characterization and antimicrobial activity of essential oils of industrial hemp varieties (Cannabis sativa L.). Fitoterapia, 81(5):413-419. https://doi.org/10.1016/j.fitote.2009.11.010 ORAVEC, V., VARGA, I., REPCAK, M., HULIKOVA, A., CERNY, J., 1988. Patent No. 245316, Office for Patents and Discoveries, Czechoslovak Republic

RAMADAN, M.M., ALI, M.M., GHANEM, K.Z., EL-GHORAB, A.H., 2015. Essential oils from Egyptian aromatic plants as antioxidant and novel anticancer agents in human cancer cell lines. Grasas y aceites, 66(2):12-19 https://dialnet.unirioja.es/servlet/articulo?codigo=5146983

RAUT, J. S., SHINDE, R. B., CHAUHAN, N. M., KARUPPAYIL, M. S. 2013. Terpenoids of plant origin inhibit morphogenesis, adhesion, and biofilm formation by Candida albicans. Biofouling. 29 (9): 87-96. http://dx.doi.org/10.4014/jmb.1402.02056

REDDY, D.N., AL-RAJAB, A.J., SHARMA, M., MOSES M., M., REDDY, G., R., ALBRATTY, M. 2017. Chemical constituents, in vitro antibacterial and antifungal activity of Mentha $\times$ piperita L. (Peppermint) essential oils. Journal of King Saud University - Science, http://dx.doi.org/10.1016/j.jksus.2017.07.013 RHOS, J.L., RECIO, M.C. 2005. Medicinal plants and antimicrobial activity. $\begin{array}{llll}\text { Journal of } & \text { Ethnopharmacology. } & \text { 100(1-2): }\end{array}$ http://dx.doi.org/110.1016/j.jep.2005.04.025

ROTA, C., CARRAMINANA, J.J., BURILLO, J., HERRERA, A. 2004. In vitro antimicrobial activity of essential oils from aromatic plants against selected foodborne pathogens. Journal of Food Protection. 67, 1252-1256 https://doi.org/10.4315/0362-028x-67.6.1252

RUSSO, E. B .2011. Taming THC: potential Cannabis synergy and phytocannabinoid-terpenoid entourage effects. British Journal of Pharmacology. 163 (7): 1344-1364. https://doi.org/10.1111/j.1476-5381.2011.01238.x

SALAMON, I. 2014. Medicinal plants of high significance in Slovakia Medicinal Plants - International Journal of Phytomedicines and Related Industries. 6 (2): 75-80. http://dx.doi.org/10.5958/0975-6892.2014.00473.0

SANTOYO, S., CAVERO, S., JAIME, L., IBANEZ, E., SENORANS, F.J., REGLERO, G. 2005. Chemical composition and antimicrobial activity of Rosmarinus officinalis L. essential oil obtained via supercritical fluid extraction. Journal of Food Protection, 68(4): $\quad 790-795$. https://doi.org/10.4315/0362-028X-68.4.790

SEMENIUC, C.A., POP, C.R., ROTAR, A.M. 2017. Antibacterial activity and interactions of plant essential oil combinations against Gram-positive and Gramnegative bacteria. Journal of Food and Drug Analysis. 25(2), 403-408. http://dx.doi.org/10.1016/j.jfda.2016.06.002

SHARMA, S., SINGH, A., BARAL, M.P., 2002. Antimicrobial activities of essential oils of some common spices. Nepal Journal of Science and Technology, 4(1). http://www.njst.nast.org.np/index.php/njst/article/view/92

YANG, H., WOO, J., PAE, A.N., UM, M.Y., CHO, N.C., PARK, K.D., YOON, M., KIM, J., LEE, C.J., CHO, S. 2016. $\alpha$-Pinene, a major constituent of pine tree oils, enhances non-rapid eye movement sleep in mice through GABAAbenzodiazepine receptors. Molecular Pharmacology, $90 \quad$ (5): 530-539, https://doi.org/10.1124/mol.116.105080 